<総 説 $>$

（受理 : 平成 27 年 7 月 29 日）

\title{
接着剂を用いず高分子材料を直接結合する新しい方法 New Paradigm of Direct Adhesion between Polymeric Materials without Bonds
}

\author{
高島 義徳 ${ }^{*}$ ・橋爪 章仁 * $*$ 山口 浩靖*・原田 明* \\ Yoshinori TAKASHIMA, Akihito HASHIDZUME, \\ Hiroyasu YAMAGUCHI and Akira HARADA
}

\section{1.はじめに}

従来，「あの」を接着するためには通常，接着剤を用い てきた。接着する材質や用途に応じて，さまざまな接着剤 が開発されてきた。接着する要因には物理的なアンカー効 果やファンデルワールスカ, 静電的な相互作用, 水素結合 などの化学的な相互作用により接着すると考えられる1 3)。 ところが，接着剤を通した接着では，接着層が介在してい るために，環境によって破断したり，凝集破壊が起こった りする場合があり，より直接的な接着が有効と考えられる。 筆者らは接着剤を介在させず，「あの」を直接結合する方 法として，「あの」どうしを反応させて直接結合させる方 法を実現した。この方法で「あの」どうしを結合で一体化 させ，溶媒などの外部環境の变化によっても剥がれない新 たな接着を実現することに成功した。

\section{2. ホストーゲスト相互作用による選択的接着}

\section{1 ホストーゲスト相互作用によるソフトマテリアル 間の接着}

筆者らはホストーゲスト相互作用に用いる分子として, ホスト分子に環状多糖であるシクロデキストリン (CD) ${ }^{4)}$ を選択しました。CD はグルコピラノース 単位が $\alpha-1,4$ 結合にて繋がれた環状オリゴ糖であります。CDの外部が 親水性であるのに対し，空孔内部は疎水的であるために， 水中では疎水性化合物を空孔内部に取り込み， CD の空孔 サイズに応じた包接錯体を形成するといった性質を示しま す。

先に我々は CD を修飾したポリアクリルアミド（pAAm） ゲル（ホストゲル）が，さまざまなゲスト分子を修飾した

* 大阪大学大学院理学研究科

大阪府豊中市待兼山町 1-1 ₹ 560-0043

Department of Macromolecular Science, Graduate School of Science, Osaka University

1-1 Machikaneyama-cho, Toyonaka, Osaka 560-0043, Japan

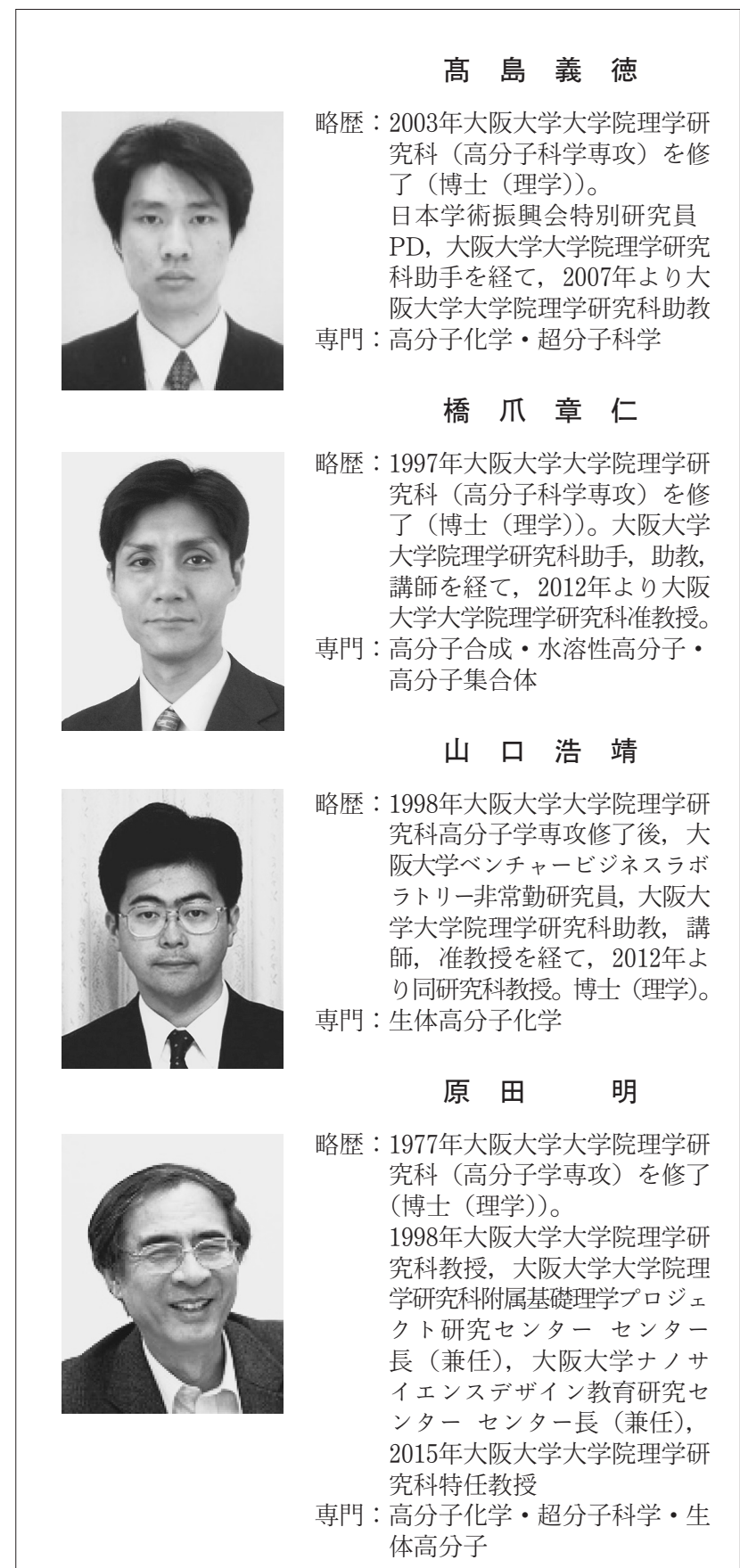


a

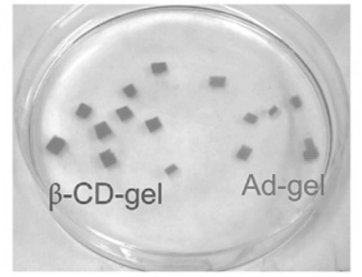

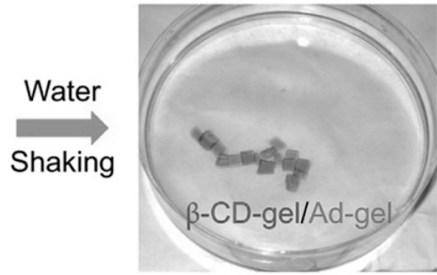

b

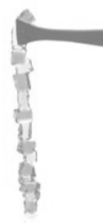

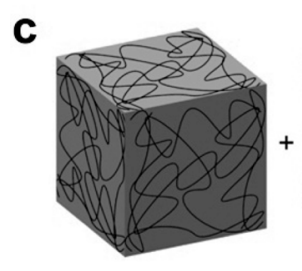
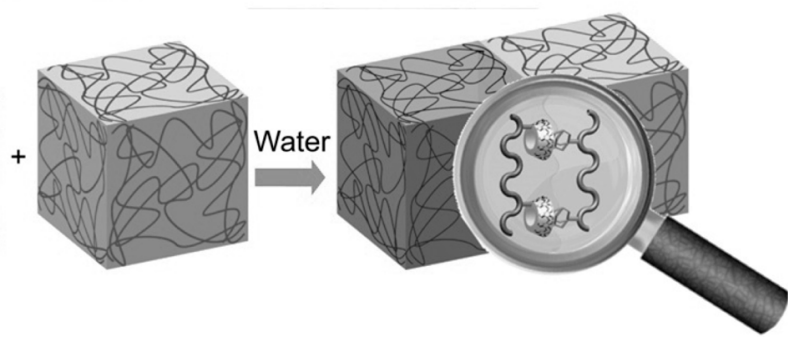

図 1 アダマンチル基が修飾されたゲストゲル（Ad gel）と $\beta \mathrm{CD}$ が修飾されたホストゲル（ $\beta \mathrm{CD}$ gel）の 選択的接着の様子（a）。接着後のゲルを乾燥させたキセロゲルの接着挙動（b） ${ }^{5)}$ 。

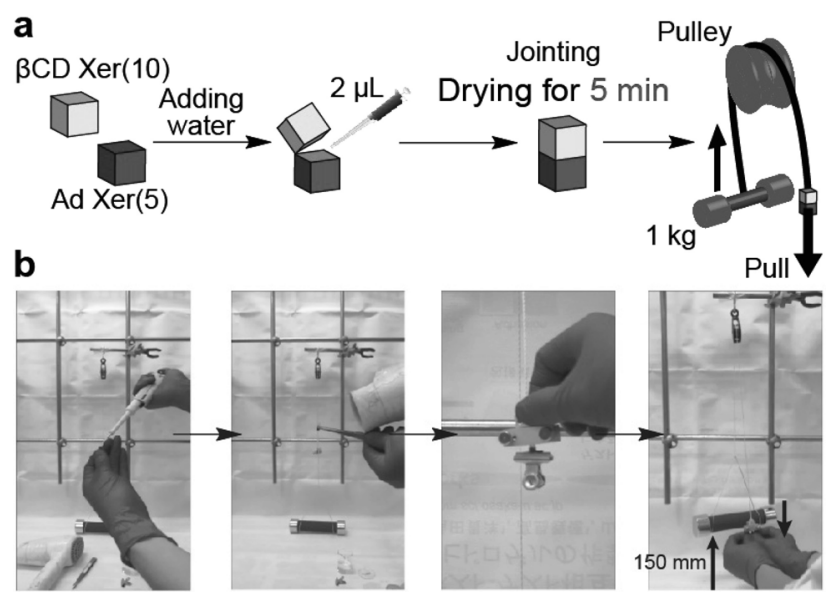

図 2 (a) Ad gel を乾燥させて得たキセロゲル (Ad Xer) と $\beta \mathrm{CD}$ gel を乾燥させたキセロゲル ( $\beta$ CD Xer) を用いた接着実験，およびダンベル $(1 \mathrm{~kg})$ の引っ 張り試験。(b) Ad Xer と $\beta$ CD Xer を接着後, ダン ベルを引っ張り上げた様子 ${ }^{6)}$ 。

pAAm ゲル（ゲストゲル）と選択的に結合することを見 いだし，報告した。特に $\beta$-シクロデキストリン（ $\beta \mathrm{CD})$ を修飾したゲル（ $\beta \mathrm{CD}$ gel）はアダマンタン $(\mathrm{Ad})$ を修 飾したゲル（Ad gel）と強く結合し，マクロスケールで の自己組織体を形成することを見いだした。この接着は選 択的であるだけでなく強力であった。接着したゲルを両端 から引っ張ったところ, 接触面では外れず, ゲル本体が破 壊された（図 1) ${ }^{5)}$ 。さらに接着させた $\beta \mathrm{CD}$ gel と Ad gel を一晚乾燥してプラスチック状のキセロゲルとした。接着 したキセロゲルは $1-2 \mathrm{~kg}$ の力で引っ張っても外れず, $3 \mathrm{~kg}$ ほどの力で引っ張ったところ, 接合面は外れず, 本 体が破壊した。次に Ad gel を乾燥させて得たキセロゲル (Ad Xer) と $\beta \mathrm{CD}$ gel を乾燥させたキセロゲル（ $\beta \mathrm{CD}$ Xer）をそのまま接触させたが，接着性は確認されなかっ た。一方で極少量 $(2 \mu \mathrm{L})$ の水をある一面に塗布し, 両 者を接触させ乾燥させると非常に強い接着性を示した。引っ
張り試験の結果, $5.1 \mathrm{MPa}$ の破断応力を示し, エポキシ 系の接着剂に匹敵する接着強度を示した。 $5 \mathrm{~mm}$ 角のキセ ロゲル同士を接着させたときには $1 \mathrm{~kg}$ のダンベルを持ち 上げられることも分かった。少量の水を塗布することによっ て分子の運動性が向上し, ホスト分子 ( $\beta \mathrm{CD})$ とゲスト 分子 (Ad) の間で包接錯体形成が促進された結果，キセ ロゲルどうしにおいても接着性が生み出されたものと考え られる(図 2 $)^{6)}$ 。この方法による接着では, 水が存在して あ接着は弱くならずむしろ水が存在することにより, より 強固に接着する。このようなホストーゲスト相互作用によ る接着は選択的な接着が可能になった。

\section{2 ホストーゲスト相互作用によるソフトーハードマ テリアル間の接着}

ゲルーゲル間（ソフト材料界面）での分子認識による接 着の結果から，硬質材料表面に修飾されたゲス卜分子をホ ストゲルは認識し, 分子認識を通して, 選択的に接着及び, 接着のスイッチングができると考えた。

ゲスト分子にはアダマンタン（Ad）やフェロセン ( Fc), さらにアゾベンゼン（Azo）を選択し，ガラス基板に修飾 した（Ad Sub, Fc Sub, Azo Sub, 図 3a)。CD の構成単 位であるグルコピラノースユニットの数が異なる $\alpha$ シク ロデキストリン $(\alpha \mathrm{CD})$ または $\beta \mathrm{CD}$ をそれぞれ修飾し たホストゲル（ $\alpha \mathrm{CD}$ gel および $\beta \mathrm{CD}$ gel）を用いてゲス ト分子が修飾されたガラス基板との接着試験を行った。 $\beta \mathrm{CD}$ は $\mathrm{Ad}$ や Fc と強く相互作用するが， $\alpha \mathrm{CD}$ は Azo と 強く相互作用するといった性質を持ちます。

$\mathrm{CD}$ 導入率の異なる複数のホストゲル（ $\alpha \mathrm{CD}$ gel およ び $\beta \mathrm{CD}$ gel）とAd Sub との接着試験を行った結果, $\mathrm{Ad}$ Subとホストゲルに接着がみられた。特に $\beta \mathrm{CD}$ gel が Ad Subに対して強い接着性を示した。これは $\beta \mathrm{CD}$ が Ad に対して，高い会合力を示す結果と考えられる。また 
$\beta \mathrm{CD}$ gel に導入した $\beta \mathrm{CD}$ の修飾濃度に比例して, 接着力 は上昇した。Azo Sub と $\alpha \mathrm{CD}$ gel の光刺激による接着制 御を試みた。Azo Sub と $\alpha \mathrm{CD}$ gel は UV 光 $(\lambda=365 \mathrm{~nm})$ を照射する前は接着したが，UV 光を照射すると接着し なかった（図 3b）。trans-Azo Sub（UV 照射前）と， cis-Azo Sub（UV 照射後）の $\alpha$ CD gel に対する接着力 を摩擦試験により評価した。その結果, trans-Azo Sub に対する接着力は, $c i s-\mathrm{Azo} \mathrm{Sub}$ と比較して大きいこと がわかった。cis-Azo 基は trans-Azo 基と比べて $\alpha \mathrm{CD}$ との相互作用が弱いため， $\alpha \mathrm{CD}$ gel は cis-Azo Subに接 着しなかったと考えられる。

(a)

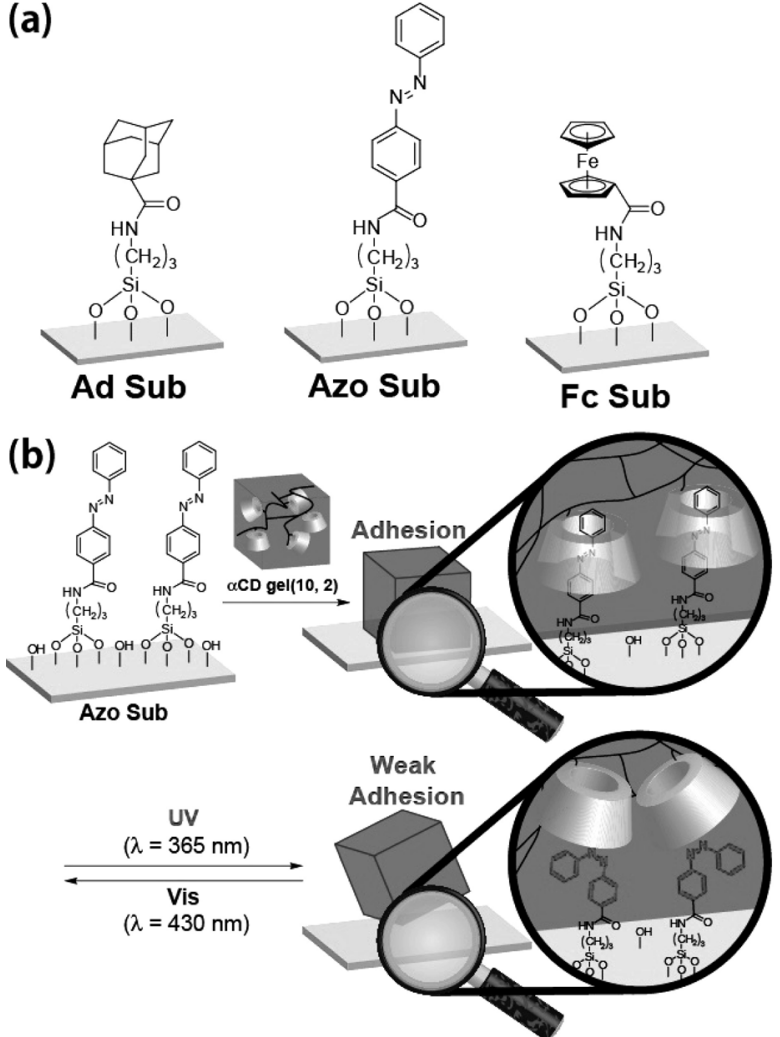

(c)

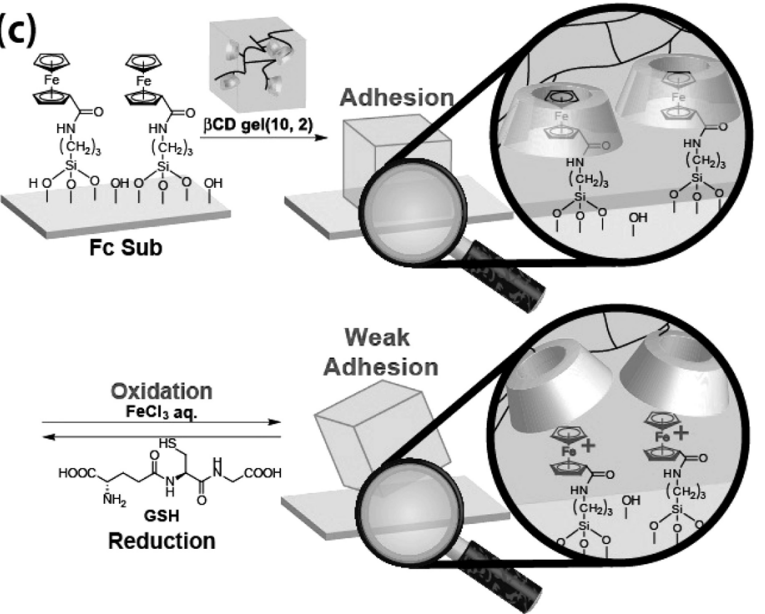

図 3 (a) Ad Sub, Azo Sub, Fc Sub の化学構造図。 (b) Azo Sub と $\alpha \mathrm{CD}$ gel との接着に抢ける光 照射応答性 ${ }^{7)}$ 。(c) Fc Sub と $\beta$ CD gel との接 着に打ける酸化還元応答性。
次に Fc Sub と $\beta \mathrm{CD}$ gel の酸化還元による接着制御を 試みた。酸化処理前の Fc Sub と $\beta \mathrm{CD}$ gel は接着した。 しかし， $\mathrm{Fc} \mathrm{Sub} \mathrm{FeCl}_{3}$ （酸化剂）の水溶液に浸漬させ たところ， $\beta \mathrm{CD}$ gel は Fc Sub に接着しなかった。中性の $\mathrm{Fc}$ 基は酸化された $\mathrm{Fc}^{+}$基と比べて $\beta \mathrm{CD}$ との相互作用が 強い。よって $\mathrm{FC}$ 基が酸化されたことによって， $\beta \mathrm{CD}$ と の錯体形成が阻害されたために酸化処理後は接着しなかっ たと考えられる7)（図 3c）。

以上より，ホストーゲスト相互作用により硬質材料一ゲ ルを光刺激や酸化還元刺激により接着性を制御できること あ明らかになった。硬質材料一ゲルの接着は，「もの」ど うしが強く結合することを発見した。

\section{3. 共有結合による接着}

このような分子間相互作用による「あの」の直接的な結 合について検討している中で，共有結合でものを接合する ことを考えた。すなわち，「むの」と「あの」を化学反応 により，直接共有結合で結合する発想である。分子同士は 化学反応するが，分子全体が反応するのではなく，分子の 一部が反応している。また，高分子同士の反応でも，高分 子すべてが反応しているわけではなく，高分子の一部が反 応している。そのように考えると，「屯の」同士も反応し て，結合することもあるのではないか，と考えた。「あの」 同士が反応すれば，「あの」同士は一体化して，外れるこ となく，強く結合する融合材料が作製できると考えた。そ こで，被着体間を共有結合形成にて接着させるために，反 応性の置換基を導入した。二つの材料の接触界面で共有結 合形成を行い，その接着力を力学的測定によって評価した。 特に共有結合による直接接着で重要な異種材料間の接着に 取り組んだ。

3.1 鈴木一宮浦カップリング反応による「もの」の結合 筆者らは共有結合形成として鈴木・宮浦カップリング反 応を選択した。鈴木・宮浦カップリング反応はパラジゥム 触媒之塩基などの求核種の作用により，有機ホウ素化合物 と八ロゲン化アリールがクロスカップリングし，ビフェニ 儿誘導体を生成する。

鈴木・宮浦カップリング反応を利用するために，フェニ ルボロン酸（PB）とヨウ化アリール（I）を別々の高分子 ゲルの側鎖に導入した。高分子ゲルの主鎖にはアクリルア ミドを選択し， $N, N$ ’メチレンビスアクリルアミドにて化 学架橋した。PB を有するゲルを PB-gel，I を有するゲル をI-gel とする（図 4a）。ゲルへの PB ユニット及び I ユ ニットの導入率は ${ }^{1} \mathrm{H}$ 磁場勾配マジック角回転（FGMAS） NMR 測定により決定した。

得られた PB-gel と I-gel を用いて, 鈴木・宮浦クロス カップリング反応による接着を試みた。 $\mathrm{PB}$ - gel と I-gel 


\section{a}

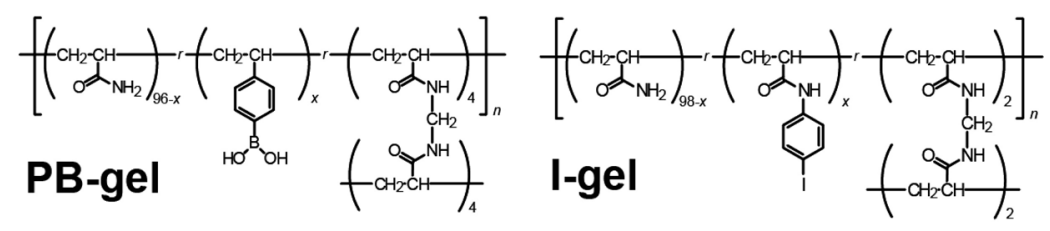

b

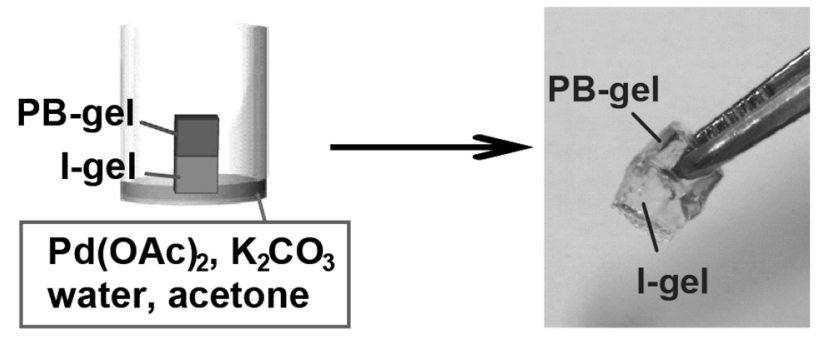

\section{C}
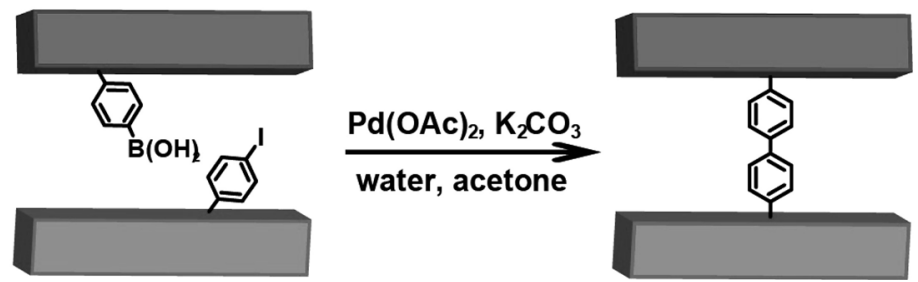

図 4 (a) PB-gel と I-gel の化学構造。（b）パラジゥム触媒を用いた PB-gel と I-gel の接着実験。 (c) 鈴木・宮浦カップリング反応による接着の推定機構 ${ }^{8)}$ 。

は $5 \times 4 \times 3 \mathrm{~mm}^{3}$ に成型し, 垂直に重称, 炭酸カリウム水 溶液と酢酸パラジウムのアセトン溶液を添加し, 所定の時 間静置させた。反応経過 10 分後から，接着性が確認され た（図 $4 \mathrm{~b}$ )。この接着はパラジウム触媒を添加しない場合 やフェニルボロン酸, 或いは, ヨウ化アリールの何れかの ユニットが存在しない場合には示さなかった。

PB-gel と I-gel の接着強度を破断試験により評価した。 その結果, 機能性官能基の導入量の増加に従って, 接着強 度は増大した。この様に接着強度は反応性官能基の導入量 に影響されており，高分子ゲル界面で鈴木・宮浦カップリ ング反応が進行し, 形成された共有結合が材料間の接着を 生み出したと考えられる ${ }^{8}$ （図 4c)。

\section{2 アジドーアルキン環化付加反応による「もの」の} 結合

先の鈴木・宮浦カップリング反応を用いた接着の実施例 をもとに，反応の多様性を調べるために，銅触媒を用いた アジドーアルキン環化付加反応（CuAAC 反応）を用いて 材料の接触界面で共有結合形成による接着を試みた。

基材となる高分子ゲルにアジド基（Az）または末端エ チニル基（E）を導入し, $\mathrm{Az}-\mathrm{gel}$ と $\mathrm{E}-\mathrm{gel}$ を作製した (図 5a)。Az-gel は銅（I ）触媒存在下, E-gel と 15 分 以内に持ち上げられるほどに接着した（図 $5 b)$ 。銅触媒を 用いない場合やアジド基, 及び末端エチニル基の何れかが 導入されていない高分子ゲルでは接着性は示さなかった。
$\mathrm{Az}$ - gel と $\mathrm{E}-\mathrm{gel}$ の接着強度を破断測定にて評価したと ころ，ゲル中のアジド基と末端エチニル基の導入量の増加 に従って，接着強度も増加した。これらの結果より， CuAAC 反応においても, 高分子ゲルの接触界面に共有結 合形成が進行し，高分子材料を接着できることが明らかと 成った（図 5c) ${ }^{9)}$ 。

\section{3 薗頭反応による「もの」の結合}

これまで紹介した高分子ゲル間の接着はヒドロゲルを用 いており，水系での接着反応であった。材料間の直接接着 は溶媒極性に依存せず，実現できると考えられる。そこで 有機溶媒にて膨潤したオルガノゲルを用いて, 薗頭カップ リング反応にて接着を試みた。薗頭カップリング反応はパ ラジゥム触媒, 銅触媒, 塩基の存在下，末端アルキンと八 ロゲン化アリールがクロスカップリングする反応であり, 通常, 有機溶媒中で行われるため, 選択した。

オルガノゲルの主鎖骨格にはポリスチレンを選択し, $p-$ ジビニルベンゼンにて架橋した。オルガノゲルは DMF 中 にて $\mathrm{AIBN}$ を開始剂としたラジカル共重合を行い，側鎖 にヨウ化アリール基を導入した I-Stygel と末端エチニル 基を導入した $\mathrm{E}$-Stygel を合成した（図 6a)。I-Stygel と $\mathrm{E}$-Stygel を Ar 雾囲気下，トリエチルアミン，パラジ ウム触媒, 銅触媒存在下で接触させた。両ゲルは 30 分以 内に持ち上げられるほどに接着した（図 6b)。この接着は, 触媒, ヨウ化アリール, 末端エチニル基の何れかが存在し 
a

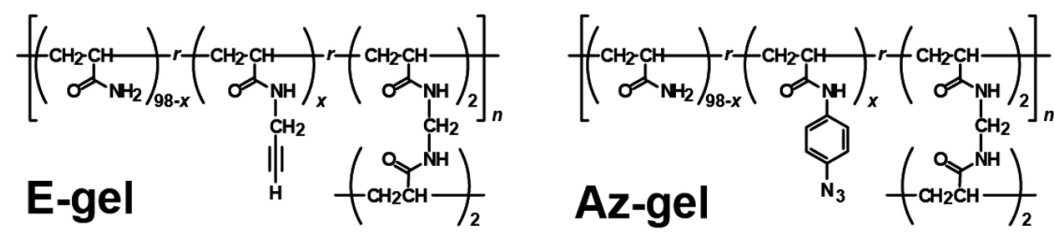

b

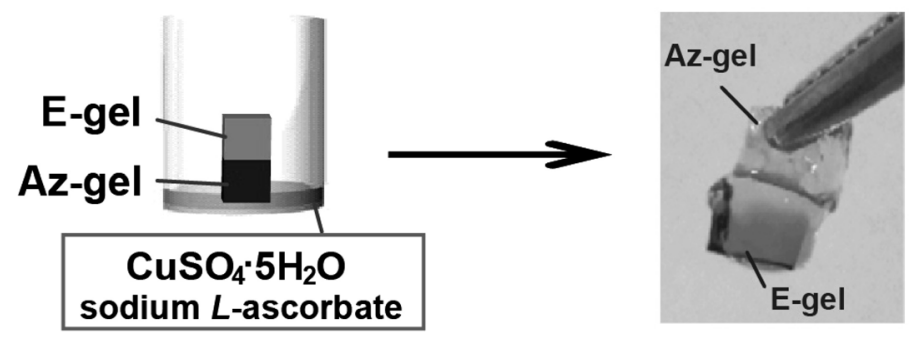

C

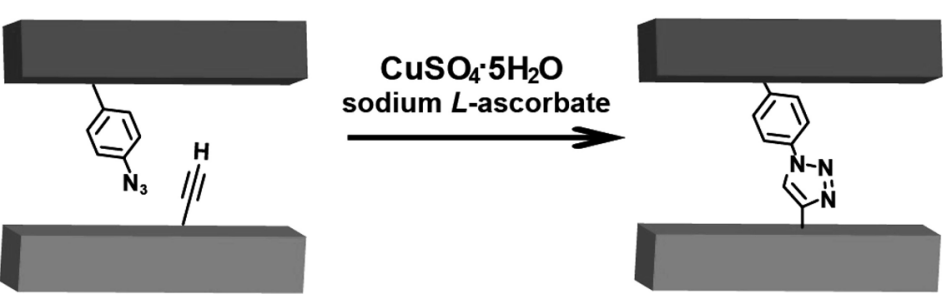

図 5 (a) $\mathrm{E}$-gel と $\mathrm{Az}-\mathrm{gel}$ の化学構造。（b）銅触媒を用いた $\mathrm{E}$-gel と $\mathrm{Az}$ - gel の接着実験。

(c) $\mathrm{CuAAC}$ 反応による接着の推定機構 ${ }^{9)}$ 。

a
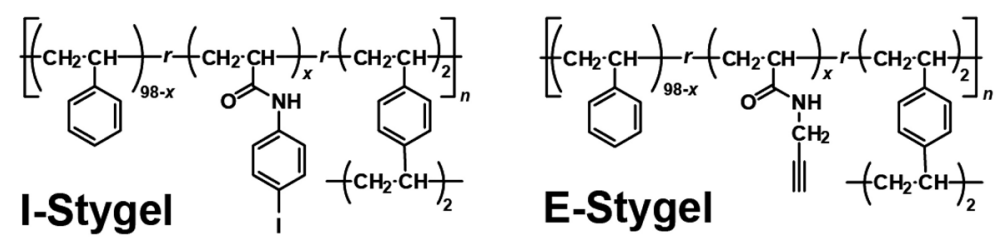

b

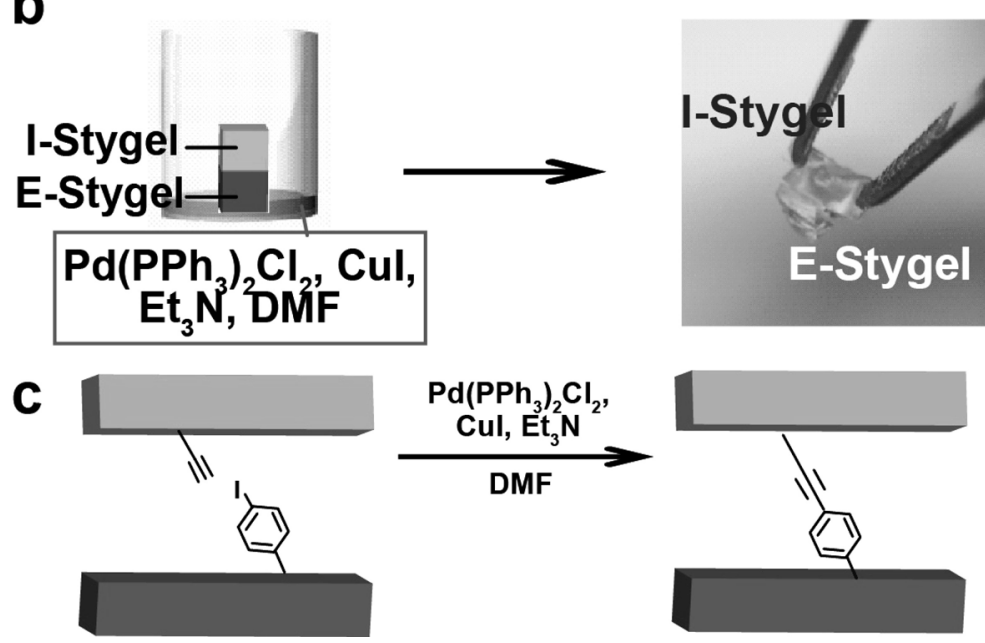

図 6 （a） I-Stygel と E-Stygel の化学構造。（b）銅触媒を用いた I-Stygel と E-Stygel の接着実験。 (c) 薗頭カップリング反応による接着の推定機構。

ない場合には発現しなかった。

薗頭カップリング反応を 24 時間行った後, 引っ張り試 験にて I-Stygel と E-Stygel の接着強度を評価した。そ
の結果, 反応性官能基の導入量が増加するに従って，ゲル の接着強度は増加した。これより, オルガノゲルの接触界 面において, 䕐頭カップリング反応が進行し, 共有結合が 
形成され，接着したと考えられた（図 6c)。

\section{4 ゲルとガラス基板との結合}

材料間の接着において, 同種の材料同士の接着は接着剂 をむちいても比較的容易に達成できる。一方で硬さや化学 的性質が異なる材料どうしを接着させることは難易度が高 く, 材料間の接着において常に課題になっている。前項で は有機材料どうしの接着である。実験結果から推察するに, 被着体の材質に影響されず，接着が実現する可能性がある。 そこで, 本項では高分子ゲルと無機材料である無機ガラス 基板との接着を試みた。

高分子ゲルと無機ガラス基板の接着には鈴木・宮浦カッ プリング反応を選択した。高分子ゲルには, 先と同様に反 応性の置換基（フェニルボロン酸基，もしくはヨウ化アリー ル基）を修飾した。硬質ガラス基板は表面の有機物の除去 と親水化を目的にオゾン処理し, シランカップリング剂 (3-アミノプロピルトリエトキシシランもしくは $3-$ グリ シジルオキシプロピルトリメトキシシラン）を表面修飾し た。その後, 反応性置換基であるフェニルボロン酸, また はヨードアニリンを反応させることにより, PB 基板 (PB -Sub), 及び I 基板（I-Sub）を作製した。ガラス基板上 の反応性置換基は X 線光電子分光分析法 (XPS) により 修飾を確認した。基板上にホウ素, およびヨウ素の存在を
確認し，PB，及びIが修飾されていることを確認した。

これらの基板と I-gel または $\mathrm{PB}$ - gel と組み合わせて接 着試験を行った。I-gel の上に PB-Sub を重的, 炭酸力 リウム水溶液, 酢酸パラジゥムのアセトン溶液を添加した。 反応開始 1 時間後には，ゲルと基板は接着した（図 $7 b, c) 。$ I-Subと PB-gel の組み合わせにおいても接着した。一 方で, 触媒である䣷酸パラジゥムが無添加の場合やボロン 酸基，またはヨウ化アリール基が導入されていない基材を 用いた場合には接着しなかった。

ガラス基板と高分子ゲルの接着強度は引っ張り試験によ り評価した。ガラス基板をサンプルステージに固定し，ゲ ルを治具で挟み引っ張り，破断応力を測定した。破断応力 はゲル側の反応性置換基の導入量が増加するに伴い，増加 した。一方で, 反応性置換基の濃度が上昇するに従って, 破断時には被着体の破壊が見られた。

この様な異種材料間の直接接着は, 従来の接着剤を用い た材料間の接着と異なる特徵を持つ。例えば，シアノアク リレート系接着剂を用いて高分子ゲルとガラス基板を接着 させた場合，接着するが，DMSO などの溶解力の強い有 機溶媒に浸漬させると, 接着剤が溶け出し, それぞれの被 着体は乘離した（図 7d, e)。しかし, 鈴木・宮浦カップリ ング反応を用いて接着させた材料は, 有機溶媒浸漬後も被 着体どうしが刋離することは無く, 接着は保持された。こ

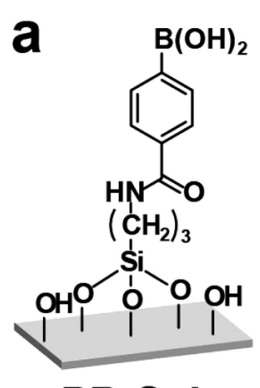

PB-Sub

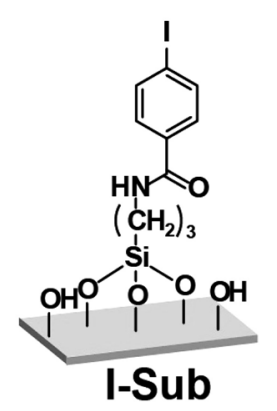

d Commercially available adhesive

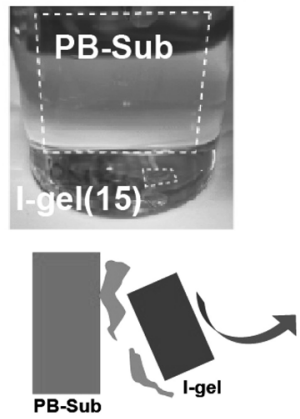

b
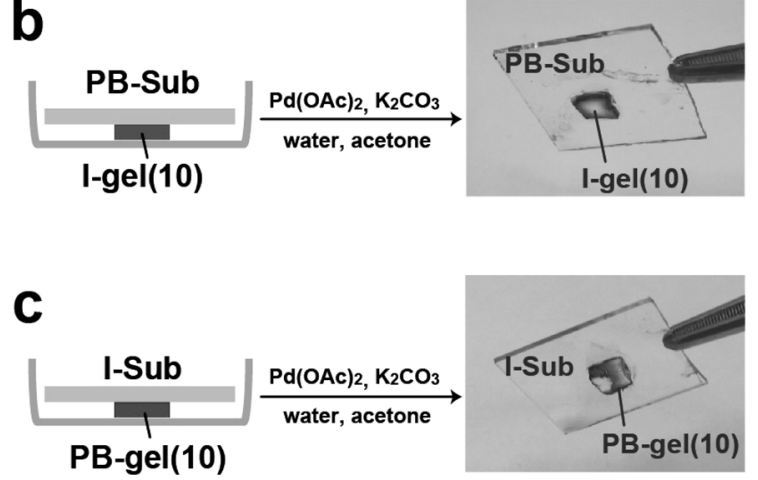

Suzuki-Miyaura coupling reaction

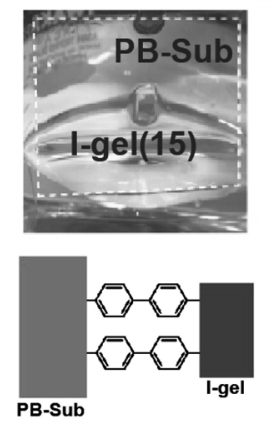

図 7 (a) PB-Sub と I-Sub の化学構造。（b）パラジゥム触媒を用いた PB-Sub と I-gel の接着実験。 （c）パラジゥム触媒を用いた PB-gel と I-Sub の接着実験。（d）市販の接着剤を用いた PB-Sub と I-gel の接着実験。DMSO に浸漬すると接着剤が溶解し, 剥離する。（e）鈴木・宮浦カップリ ング反応による PB-Sub と I-gel の接着物の DMSO 浸漬実験。DMSO に浸漬させても剥離は見 られない。 
れは両者が共有結合で接合されているためと考えられる99。

\section{4. 結 論}

今回，材料間の接着を非共有結合または共有結合形成に よって直接接着させる研究を紹介した。非共有結合による 接着ではホストーゲスト相互作用により接着させた。その 接着力は比較的強い結合であることが分かった。乾燥させ たキセロゲルの状態においても界面に僅かな水を添加させ ることで接着させることが可能であることが分かった。非 共有結合を用いた接着であるため，結合は可逆であり，繰 り返し接着させることができる。

共有結合形成による接着では，鈴木・宮浦カップリング 反応やアジドーアルキン環化付加反応（CuAAC 反応）, さらには薗頭カップリング反応を用い，材料間の直接接着 させた。今回，代表例として，3 種の反応を紹介したが， アミド結合形成についても成功しており，結合形成の適用 範囲は広い。直接接着の特徵は接着層が存在しないことに ある。接着した材料同士は共有結合を通して接合されてお り，通常の接着剂を用いた接着には無い安定性がある。異 種材料どうしでありながらも，あたかも新しい物体が構築 できている点が興味深い。

今後，接着させたい環境や材質に応じて，非共有結合ま たは共有結合を選択することが出来る。これらの接着方法 により，これまで接着が困難であった材料どうしを接着す る技術として発展することが期待される。

\section{文献}

1) W. Brockmann, P. L. Geiß, J. Klingen \& B. Schröder "Adhesive Bonding: Adhesives, Applications and Processes”, Wiley-VCH, Weinheim (2009).

2) H. Onusseit, et al. "Adhesives, 1. General in Ullmann's Encyclopedia of Industrial Chemistry”, Wiley-VCH, Weinheim (2010).

3）（a）“最新の接着・粘着技術 Q\&A”, 産業技術サービスセン 夕- (2013)

（b）“接着工学 一接着剂の基礎，機械的特性，応用-” R. D. Adams 編，佐藤千明監訳，NTS (2008).

4) J. Szejtli, Chem. Rev., 98, 1743 (1998).

5) A. Harada, R. Kobayashi, Y. Takashima, A. Hashidzume, H. Yamaguchi, Nat. Chem., 3, 34 (2011).

6) T. Kakuta, Y. Takashima, T. Sano, T. Nakamura, Y. Kobayashi, H. Yamaguchi, A. Harada, Macromolecules, 48, 732 (2015).

7) Y. Takashima, T. Sahara, T. Sekine, T. Kakuta, T. Nakahata, M. Otsubo, Y. Kobayashi, A. Harada, Macromol. Rapid Commun., 35, 1646 (2014).

8) T. Sekine, T. Kakuta, T. Nakamura, Y. Kobayashi, Y. Takashima, A. Harada, Sci. Rep., 4, 6348 (2014).

9) T. Sekine, Y. Takashima, A. Harada, RSC. Adv., 5, 56130 (2015). 